\title{
Viable Facets of World Wide Web as an Advertising Media for Creating an Impact on the Buying Behavior
}

\author{
Dr. K. Pongiannan \\ M.Com, M.Phil., PhD., MBA \\ Associate Professor and Head \\ Department of e-Commerce \\ Kongunadu Arts \& Science College, \\ Coimbatore, Tamilnadu, India.
}

\begin{abstract}
The World Wide Web as an advertising media is considered to be a powerful advertising media because of the directionality of the advertising message where the consumer searches for an advertisement in contrast to the traditional advertisements. Moreover, the importance of presentation as much as its content plays a vital role in making web as a high-quality media to attract the consumers through the advertisements hosted on it. In addition, there are various features which make Web as an authoritative source for effective advertisements which influences the consumers for their purchase decision. The present study is a descriptive study which analyses these features which authenticates the World Wide Web as a viable advertising media which influences the consumers for their purchase decision. The study was done using a well structured questionnaire collected from 1001 respondents located in Coimbatore city of India using snow ball sampling technique. The captured responses were subjected to descriptive analysis using Frequency, Chi-Square, Friedman Two Way ANOVA and Regression. It was found that, the possibility of updating about new products, options for electronic marketing, detailed information about the product (including its price, availability, quality and varieties), responses to queries and good recall and retention value of the web advertisements plays an important role in making the World Wide Web as a powerful media for advertisements.
\end{abstract}

Keywords: WWW, Web advertisements, Internet, buying behavior

\section{INTRODUCTION}

The World Wide Web, the most popular commercial component of Internet is currently being used for a variety of purposes. (George. E. Belch and Michael. A. Belch, 2001). There are web pages that are used to provide a variety of useful content, including government information at federal, state, and local levels, academic information, ranging from electronic journals to the delivery of course content, and reference information, including online library catalogs and collections of links to other Web sites organized by subject. There are pages that are ongoing and interactive works of art, which exploit the visual and textual capabilities of the Web. At the other extreme, there is business on the Web. There are many companies that are conducting business on the Web, selling their products in a variety of ways. For example, there are growing numbers of publishers who are providing information about selling their publications.

Several researches in the field of web advertising have been conducted and the implications for better web advertising were followed. Schumann and Thorson (1999) found that marketers benefit from the interactivity characteristic of Web advertisements by having the ability to reach specific target markets and find new customers more easily. Moreover, marketers can track the usage patterns of their customers and their target markets and through a variety of marketing efforts, create loyalty.

Cappo (2003) claims that being able to gather information before the purchase of product or service is becoming ever more important in today's Internet age. Web advertisements allow the user to get more information about the product before making purchase decision. This adds value to Web advertising among the consumers.

Stafford and Fabre (2005) in their study on advertising promotion in Web found that the interactivity in Web offers the users convenience, diversion, relationship development and intellectual appeal. Moreover, they found that with the interactive value of a medium, the consumers are able to control their communication experiences because they choose the information that they consume, which is possible in Web media.

$\mathrm{Ng} \mathrm{Ka} \mathrm{Po} \mathrm{(2006)} \mathrm{analyzed} \mathrm{the} \mathrm{factors} \mathrm{affecting} \mathrm{the} \mathrm{attitude}$ towards Web advertising. The results showed that only the advertisement content and brand name are affecting the attitude toward the Web advertisements. Advertisement content which is highly related to the content of the host site can lead to a more favourable attitude toward the Web advertisements. Famous brand name would make the reader develop a more favourable attitude towards the Web advertisements than the nameless brand. The results also showed that the positive attitude toward the Web advertisements would evoke positive attitude toward the purchase intention.

Thus, the past studies have enlightened the researcher to study the facets of web advertising that influences purchase behaviour.

\section{METHODOLOGY}

The present study is based on the descriptive study using primary data to investigate the objectives and testing the hypotheses. A well-structured questionnaire was used as an instrument to collect the data. The data used for the purpose of analysis of this study were collected for a period of one year from $1^{\text {st }}$ June 2009 to $31^{\text {st }}$ May 2010.

\subsection{Objectives of The Study}

The present study is based on the following objectives:

- To identify the most preferred website for viewing advertisements. 
- To know the reasons and frequency of viewing advertisements in World Wide Web.

- To identify the preferred form of Web advertisements

- To examine the factors that influences the buying behaviour of the respondents after seeing advertisements in Web.

\subsection{Sampling Frame}

The geographical area of Coimbatore city was chosen as the Universe. The main reason for choosing Coimbatore City is that the investigator is located here and is familiar with the place.

\subsubsection{Sampling Technique}

The Questionnaire was administered in person randomly to a majority of respondents in the study area of Coimbatore City, after oral confirmation that they are actively involved in using web as an advertisement source. Also, Snowball Sampling Technique was used to select the respondents who are stationed faraway from the researcher. On this basis the questionnaire was administered to 1,300 respondents with a yielding rate of $77.1 \%$ (1001 usable Questionnaires).

\subsection{Techniques Used for Analysis}

The techniques used for analysis are i) Descriptive statistics such as frequency analysis and cross tabulation ii) Nonparametric tests such as Chi-Square test and Friedman TwoWay ANOVA and iii) Multiple Regression analysis.

\section{ANALYSIS AND INTERPRETATION}

The data for the present study collected from the respondents through Questionnaire were tabulated and analyzed using appropriate statistical techniques mentioned in the research methodology. The results from the statistical analysis and the objective-wise analysis of the study are presented in this section. All the numerical results of the percentage analysis are rounded off to the first significant digit.

\subsection{Respondents' order of preference for Websites as advertising media}

To know about the respondents' order of preference for the different websites for viewing advertisements, the respondents' were requested to rank their favourite website for viewing advertisement and mean ranks were calculated using Friendman- Two way ANOVA. Also the test for significant difference in the preference of websites for advertisements, Chi-square analysis was conducted. The results are given below.

Ho: There is no significant difference in the preference of websites for advertisements

H1: There is significant difference in the preference of websites for advertisements

Table 1 Respondents' order of preference for websites as advertising media

\begin{tabular}{|c|c|c|c|}
\hline SI No. & Description & $\begin{array}{c}\text { Mean } \\
\text { Rank }\end{array}$ & $\begin{array}{c}\text { Chi-Square } \\
\text { (Sig) }\end{array}$ \\
\hline 1 & Yahoo & 2.42 & \\
2 & Rediff & 2.98 & 1842.312 \\
3 & Google & 2.73 & $(0.000)$ \\
4 & Hotmail & 3.51 & \\
5 & Indiatimes & 3.79 & \\
6 & Others & 5.57 & \\
\hline
\end{tabular}

The above Table 1 shows the results of Friedman Two-Way ANOVA. It is obvious from chi-square value $=1842.312$; $=0.000$ that there is a significant difference in the choice of websites for advertisements. Hence, Ho is rejected and $\mathrm{Hl}$ is accepted at $5 \%$ level of significance.

On examination of the mean ranks it is seen that yahoo is the first preferred website (mean rank $=2.42$ ) followed by google $($ mean $=2.73)$; rediff $($ mean $=2.98)$; hotmail $($ mean $=3.51)$; Indiatimes $($ mean $=3.79)$; and others $($ mean $=5.57)$

\subsection{Reasons for viewing advertisements in Web}

The reasons for which the respondents' used web for viewing their advertisements were analysed using Friedman Two way ANOVA and test of significance was performed using Ch-Square. The null and alternative hypotheses are,

Ho: There is no significant difference in the reasons for surfing website for advertisement

H1: There is significant difference in the reasons for surfing website for advertisement

Table 2 Tabulation on reasons for surfing website for advertisement

\begin{tabular}{|l|c|}
\hline \multicolumn{1}{|c|}{ Description } & Mean Rank \\
\hline To update about new product & 1.97 \\
information & 2.26 \\
To make buying decision & 2.45 \\
For e-marketing activities & 3.32 \\
Others & \\
\hline
\end{tabular}

Chi-square $=608.821 ; \mathrm{p}=0.000$

The above Table 2 shows the results of Friedman Two-Way ANOVA. It is clear from the chi-square value $=608.821 ; \mathrm{p}$ $=0.000$, that there is significant difference in the reasons for using websites for advertisements. Hence, Ho is rejected and $\mathrm{H} 1$ is accepted at $5 \%$ level of significance.

On examination of the mean ranks, it is seen that availability of updated new product information is the first reason (mean rank $=1.97$ ), followed by convenience for buying decision $($ mean $=2.26$ ); e-marketing activities (mean $=2.45)$ and others $($ mean $=3.321)$.

\subsection{Frequency of viewing advertisements in Web}

To fulfill the objective of knowing the frequency of viewing advertisements in Web, percentage analysis was used and test for significant difference in the frequency of seeing advertisements, chi-square was conducted. The following are the appropriate null and alternative hypotheses:

Ho: There is no significant difference in the frequency of seeing advertisements in Web

H1: There is significant difference in the frequency of seeing advertisements in Web

Table 3 Tabulation on frequency of seeing advertisements in Web

\begin{tabular}{|c|c|c|c|c|}
\hline Description & Frequency & Percent & $\begin{array}{c}\text { Cumulative } \\
\text { Percent }\end{array}$ & $\begin{array}{c}\text { Chi- } \\
\text { square } \\
\text { (sig) }\end{array}$ \\
\hline Not at all & 164 & 16.4 & 16.4 & \multirow{3}{*}{$\begin{array}{l}95.795 \\
(0.000)\end{array}$} \\
\hline occasionally & 252 & 25.2 & 41.6 & \\
\hline Frequently & 373 & 37.3 & 78.8 & \\
\hline
\end{tabular}




\begin{tabular}{|l|c|c|c|c|} 
Daily & 212 & 21.2 & 100.0 & \\
Total & 1001 & 100.0 & & \\
The above Table 3 shows that $21.9 \%$ of the
\end{tabular}

The above Table 3 shows that $21.9 \%$ of the respondents watch advertisements daily; $37.3 \%$ of them frequently; $25.2 \%$ of them occasionally and $16.4 \%$ of them do not watch advertisements in web.

Chi-square results $(=95.795)$ show that there is significant difference $(\mathrm{p}=0.000)$. Hence, Ho is rejected and $\mathrm{Hl}$ is accepted at 5\% level. This indicates that the frequency of watching advertisements in web among the respondents is different.

\subsection{Forms of Web advertisements}

There are different forms of Web advertisements such as banner, Pop-up, Interstitials, logos and e-mail. To rank these forms based on respondents' preference, Friedman Two-way ANOVA was used. To test for significant difference in the ranking of the different forms of Web advertisements, Friedman Two-Way ANOVA was conducted. The null and alternative hypotheses are,

Ho: There is no significant difference in the ranking of the forms of web advertisement

H1: There is significant difference in the ranking of the forms of web advertisement

Table 4 Tabulation on the ranking of the different forms of web advertisement

\begin{tabular}{|c|c|}
\hline Description & Mean Rank \\
\hline Banner ad & 2.56 \\
Pop - ups & 2.70 \\
Interstitial ads & 3.38 \\
Logos & 3.17 \\
Emails ads & 3.19 \\
\hline
\end{tabular}

Chi-square $=197.415 ; p=0.000$

The above Table 4 shows that chi-square statistic is 197.415 which is significant. Hence, Ho is rejected and H1 is accepted at $5 \%$ level of significance.

On examination of the mean ranks, it is evident that the banner advertisements are the first preferred (mean rank $=2.56$ ) followed by Pop-ups (mean rank $=2.70$ ); logos (mean rank $=3.17$ ); email ads (mean rank $=3.18$ ) and Interstitial (mean rank $=3.38$ ).

3.5. Factors that influence the purchase behaviour of the respondents after seeing advertisements in the Web

To study the factors that influence the buying behaviour of the respondents after seeing the advertisements in the web, multiple regressions was conducted. The independent variables are the items that captured the opinion of the respondents about advertisements released in web and the dependent variable is the buying behaviour of the respondents after seeing advertisements released in web. The composite mean of the items that captured the buying behaviour was taken as the data for the dependent variable. To test for significant difference, the following hypotheses were framed:

Ho: There is no significant relationship between the perception on the advertisements released in web and buying behaviour after seeing the advertisements in web

H1: There is significant relationship between the perception on the advertisements released in web and buying behaviour after seeing the advertisements in web

Table 5 Tabulation on Regression results predicting the buying behaviour after seeing advertisement in the web

\begin{tabular}{|c|c|c|c|}
\hline Items & $\begin{array}{c}\text { Standardized } \\
\text { Coefficients } \\
\beta\end{array}$ & $\mathbf{t}$ & Sig. \\
\hline \begin{tabular}{|l} 
(Constant) \\
\end{tabular} & & 12.538 & 8.000 \\
\hline $\begin{array}{l}\text { Advertisements are more } \\
\text { attractive }\end{array}$ & -.025 & -.896 & .371 \\
\hline $\begin{array}{l}\text { Advertisement arrests my } \\
\text { attention }\end{array}$ & .477 & 16.580 & 0.000 \\
\hline $\begin{array}{l}\text { Like to view the advertisements } \\
\text { again and again }\end{array}$ & .145 & 5.304 & .000 \\
\hline Advertisements are believable & .125 & 4.644 & .000 \\
\hline Easy to understand & -.042 & -1.512 & 2.131 \\
\hline $\begin{array}{l}\text { Quality of the product is well } \\
\text { understood }\end{array}$ & .004 & .139 & .889 \\
\hline $\begin{array}{l}\text { Clarity of information about the } \\
\text { product }\end{array}$ & .044 & 1.553 & .121 \\
\hline $\begin{array}{l}\text { Depth of information about the } \\
\text { product }\end{array}$ & -.009 & -.314 & .753 \\
\hline Creative product description & .019 & .693 & .488 \\
\hline $\begin{array}{l}\text { Attractive caption and } \\
\text { presentation style }\end{array}$ & .066 & 2.357 & .019 \\
\hline Connecting to global market & .009 & .332 & .740 \\
\hline Round the clock accessibility & .051 & 1.872 & .061 \\
\hline $\begin{array}{l}\text { Response to queries post } \\
\text { advertisements such as telephone, } \\
\text { email etc., }\end{array}$ & -.007 & -.256 & .798 \\
\hline $\begin{array}{l}\text { I could comprehensively recall the } \\
\text { ads released in this media about } \\
\text { the product / brand I intend to } \\
\text { buy. }\end{array}$ & .055 & 2.009 & .045 \\
\hline $\begin{array}{l}\text { I can correctly discriminate the } \\
\text { product / brand as having been } \\
\text { seen or heard before through the } \\
\text { ad released in this media }\end{array}$ & -.023 & -.864 & .388 \\
\hline $\begin{array}{l}\text { I could very well recall the } \\
\text { benefits of the product / brand } \\
\text { after seeing the ad released in this } \\
\text { media }\end{array}$ & -.015 & -.534 & .594 \\
\hline $\begin{array}{l}\text { This ad creates strong feelings } \\
\text { about the product / brand }\end{array}$ & .034 & 1.204 & .229 \\
\hline $\begin{array}{l}\text { I will not feel difficult if I am } \\
\text { asked to give the overall feelings } \\
\text { on the product/brand after seeing } \\
\text { the advertisement. }\end{array}$ & .009 & .318 & .750 \\
\hline $\begin{array}{l}\text { Ads released in this media } \\
\text { provides me complete satisfaction }\end{array}$ & .027 & .964 & .335 \\
\hline $\begin{array}{l}\text { I rely on the ads released in this } \\
\text { media for information }\end{array}$ & .042 & 1.561 & .119 \\
\hline
\end{tabular}

$\mathrm{R}^{2}=0.435 ;$ Adjusted $\mathrm{R}^{2}=0.424 ; \mathrm{F}=37.755 ; \mathrm{p}=0.000$

The regression coefficient Table 5 is given above. $\mathrm{R}^{2}=0.435$ and adjusted $\mathrm{R}^{2}=0.424$. This means that $42.4 \%$ of the total variance in the dependent variable is explained by the independent variables. $F=37.755$ which is significant at 0.05 level. This means that the model is fit. On examination of the Coefficient table, it was found that the item aadvertisements arrests my attention $(\beta=0.477 ; p=$ $0.000)$; Like to view the advertisements again and again ( $\beta$ $=0.145 ; \mathrm{p}=0.000) ;$ Advertisements are believable $(\beta$ $=0.125 ; \mathrm{p}=0.000)$; Attractive caption and presentation style ( $\beta=0.066 ; p=0.019)$; I could comprehensively recall the ads released in this media about the product / brand I intend to buy $(\beta=0.055 ; p=0.045)$. Hence, Ho is rejected and H1 is accepted for the above variables. 


\section{4. EXCELLENCE IMPLICATIONS ADVERTISEMENTS IN WEB

Although the web is highly popular for accessing information through email and browsing, it also can be much admired for advertisements. Moreover the respondents suggest that the standard of advertisements in Web media should be improved. Hence, following are the implications that are proposed to web media planners, web advertisers and marketers for excellence of advertisements in Web media:

It is obvious from this study that the respondents expect more product information to create a value about the advertised product. Hence it is suggested that sufficient information about the product including price, quality, availability, special offers, guarantees and warranties should be available in the advertisement. The web media is often considered as a sales tool which enables immediate purchase of the product by means of online marketing. Hence it is suggested that assurances to prevent fraud, satisfaction, and prompt delivery of the product should be posted in the advertisement. The Web media can incorporate the multimedia content in its advertisements. Hence it is possible to let the customer to sample the product. For example, Listening to a sound clip or previewing a book chapter is being facilitated in web media. So it is suggested that the advertisements for products such as books, audio and video compact discs, appliances can be hosted in the web to enable direct selling.

Majority of the respondents are of the opinion that the web is an interactive advertisement media. However, trust and confidence about the advertised product can be acquired only if the advertisers respond to their queries promptly. Hence, it is suggested that the advertisers should take steps to ensure that the customers' queries are answered in time. Also, the respondents feel a kind of insecurity while providing their personal information during posting queries and interaction with the advertiser. As a result, the advertisers lose their valuable customers who do not even send a query about the advertised product. Hence, this area should be concentrated. The respondents are of general perception that the high downloading time for a web page inhibits their interest about the advertisement. Hence, the media owners should eliminate such technical faults to satisfy the web users.

\section{CONCLUSION}

With the advent of technology, Web is becoming a popular media of advertisement. The Web media potentially offers the benefits such as the ability to give up-to-date accurate content with interactivity and supportive to draw conclusions about the product which enhances the value of advertisements. Also, the advertisements in this media have round the clock accessibility that can be connected globally. Hence, it provides a greater opportunity for Web based direct marketing. Thus, this paper, which accounts for the preferences of the users of web about its effectiveness in advertisements has revealed the importance of internet in creating purchase desire for products and hence increased its market potential.

\section{REFERENCES}

[1[ George E. Belch and Michael A. Belch, (2001), Advertising and Promotion, Tata Mc Graw Hill, New Delhi. pg. 114-115; 355-357; 495; 506-507; 516-517.

[2] Schumann. D. W., \& Thorson. E. (1999), Advertising and the World Wide Web. Mahwah, NJ: Lawrence Erlbaum Associates.

[3] Cappo. J. (2003), The Future of Advertising: New Media, New Clients, New Consumers in the PostTelevision Age, New York, NY: McGraw Hill

[4] Stafford. M. R., \& Faber, R. J. (2005), Advertising, Promotion, and New Media, Armonk, NY: M.E. Sharpe.

[5] Ng Ka Po(2006), A thesis on Factors affecting attitude toward web advertising, Hong Kong Baptist University, Hong Kong. 